\title{
Research on the PPP Model of Community Home- Based Care in China
}

\author{
Sui Dangchen ${ }^{1}$ Li Meng ${ }^{2 *}$ \\ International Business School, Shaanxi Normal University \\ Xi'an 710062, Shaanxi, China
}

\begin{abstract}
In order to promote the development of the PPP pension service industry under the wave of population aging, this paper studies the mode of PPP entering into the community home care pension. We review the status quo of this new type of old-age care model from outside to inside and profoundly analyze causes of existing problems. The results show that there are some problems such as government power rent-seeking, lower private capital participation, and incomplete PPP pension payment mechanism. From the roots of these problems, the paper proposes that government should formulate corresponding laws and policies, increase policy support for private enterprises and improve the social security system. The analysis of this paper shows that government departments should gradually enhance their capacity for performing duties in practice, and promote the PPP model of community home-based care to develop in the direction of normalization.
\end{abstract}

Keywords-PPP model; Community home-based care; Government departments; Population aging

\section{INTRODUCTION}

China's pension situation is grim. According to the latest statistics of the elderly population released by the National Bureau of Statistics on January 18, 2018, at the end of 2017, the population aged 60 and over in China was 24.09 million, accounting for $17.3 \%$ of the total population, the population aged 65 and over was 15.83 million, accounting for $11.4 \%$ of the total. Therefore, the issue of elderly care for the elderly has become the focus of widespread social concern. In China, as the 421 model has gradually become the basic family structure in China, the traditional family pension function is declining. However, institutional pensions are expensive and the beds are insufficient. The combination of two traditional forms of oldage pension in the community is more in line with China's national conditions. At present, after China's economic growth slows down, the growth rate of fiscal revenue has also been reduced. As a result, the pressure on the government's fiscal expenditure has increased, and simply relying on financial subsidies cannot build a complete and systematic pension service system. Under this background, the PPP model that advocates the joint action of government capital and social capital has the characteristics of risk-sharing and benefitsharing. It can effectively alleviate capital requirements, fill up the obvious shortcomings of community-based retirement care services, and calmly respond to the silver tide arrival.

Many scholars have actively made a discussion. Wang Wei

About the author: Sui Dangchen (1963-), male, Linyi, Shaanxi, Professor of International Business School, Shaanxi Normal University, doctoral tutor, mainly engaged in public finance, social security and organizational behavior research; 2 Li Meng (1995-), Female, Yuncheng, Shanxi, Master graduate student of International Business School, Shaanxi Normal University, mainly engaged in public finance theory research.
(2016) used the existing problems in Shanghai community home-based care as an example to study whether the PPP model can be applied to community home care services. $\mathrm{He}$ pointed out that the PPP model can not only solve the problem of lack of funds, but also improve service quality and management efficiency [1]. Xu Mengwei (2017) researched the model of PPP docking community home-based care for the aged and summed up three forms of government-led, enterprise-led, and non-profit organization-based [2]. Cao Lei (2017) believes that the risk aversion measures adopted by the YaoJiayu Ecological Pension Center in Zibo City can provide experience for the development of the PPP community homebased pension model [3]. Gao Kaiying (2015) believes that the introduction of the PPP model in the community home-based pension service can solve problems such as insufficient funds, and pointed out that the PPP model is not just a form of financing, but requires the public and private sectors to share the corresponding functions to achieve Win-win operating management model [4]. Yang Hairong and Ding Fuxing (2017) found that the long-term care service PPP supply in Suzhou has a binary paradox of value selection and a lack of professionalism in service. Based on this, it proposes countermeasures and suggestions [5]. Li Wenqin, Shi Yuanru, and $\mathrm{Li}$ Ling (2017) identified the main risks of the PPP projects in the pension institutions, theoretically analyzed the project's six kinds of risks including trust risk and government credit risk, and proposed a series of measures for risk sharing of the project's main participants [6].

From the existing research, domestic scholars focus on the feasibility of studying the combination mode of PPP and community home-based pension, and analyze the shortcomings of the PPP pension program from the inherent risks of the PPP model. It can be seen that scholars have very little research on the problems existing in the community PPP home-based pension system and the causes of the problems. Based on this, this article explores the problems existing in the PPP model of the current community home-based pensions and proposes solutions to promote the development of PPP pension service industry. 


\section{THE ANALYSIS OF STATUS QUO OF PPP MODEL FOR COMMUNITY ENDOWMENT IN CHINESE COMMUNITIES}

As the PPP model continues to heat up, more and more areas are trying to introduce social capital, and the pension sector is no exception. As of the end of 2017, the data from the PPP project library published by the Ministry of Finance and Government and Social Capital Cooperation Center shows that there are 135 PPP pension projects distributed in 24 provinces, municipalities, and autonomous regions across the country, accounting for $1.9 \%$ of the total number of project management libraries. However, there are too few successful cases of PPP projects for the aged, and the PPP model for community-based pensions in our country lacks experience that can be used for reference. There are some problems that need to be resolved, mainly in the following aspects.

\section{A. The issue of rent seeking for power}

In the process of the PPP pension program, the power rentseeking behavior is as follows:

At the initiation stage of the project, the Ministry of Finance stipulates that all projects must go through two procedures of value for money demonstration and financial affordability when they are put into use. However, the investigation found that these two arguments of many old-age PPP projects are just a walk away process [7]. When arguing for the financial affordability of the old-age PPP project, it is required that the old-age PPP project cannot exceed $10 \%$ of the budget expenditure. Some governments will inevitably rely on PPP projects to stimulate economic growth and lay hidden dangers for later fiscal expenditures, so that the arguments are in a form. In addition, the evaluation of value for money in the pension PPP model is also problematic. For example, the private sector's rent-seeking behavior will lead to collusion with the government departments, reporting false data, and making the project evaluation muddled.

At the tendering and signing stage of the project, the tenderer helped the bidder win the bid through black box operations, weakening market competition and market adjustment measures. The government's power to rent-seeking behavior may lead to qualified companies failing to win the bid, and unsuitable personnel may gain access to management projects. This will inevitably lower the efficiency of the PPP pension program, resulting in great waste of resources, and it will cause the project to fail more seriously.

\section{B. Private capital participation is not high}

Since PPP projects are implemented through the introduction of social capital, the participation of private capital has received extensive attention. According to the data provided by Mingshu Data, private capital has not actively participated in PPP projects. From 2014 to March 2018, private non-listed capital turnover was $1,652.43$ billion RMB, accounting for $16.04 \%$ of the total turnover of PPP projects; private listed capital turnover was 927.03 billion RMB, accounting for $9 \%$. It can be seen that the private capital turnover is only $25 \%$. In addition, the number of private capital transactions was 3281, accounting for $46.77 \%$ of the total. Although the number of transactions was similar, the private capital's participation in the PPP project was relatively low in view of the transaction amount.

\section{The PPP pension model's payment mechanism is not perfect and aggravates the burden of the elderly}

There are three main ways of PPP project company's operating cost compensation and profit acquisition, namely user payment, government payment and feasibility gap subsidy. From the national PPP integrated information platform project library, as of the end of March 2018, the management library had 135 pension programs, and the user's payment in the return mechanism accounted for $65 \%$ of the total, and the proportion of feasibility gap subsidies was $33 \%$, while the government pays only $2 \%$. The main use of the products and services provided by the old-age PPP project is the elderly population. It can be seen that the government has a serious tendency to promote the pension problem to the society, which increases the burden on the elderly.

\section{ANALYSIS OF THE CAUSES OF PROBLEMS IN THE PPP MODEL OF COMMUNITY ENDOWMENT IN CHINA}

\section{A. Slow construction of relevant legal systems and power restriction mechanisms}

The application of the PPP model to the pension industry has only appeared in recent years, and many relevant laws and regulations are not sound. On the whole, there are many problems such as the low level of the PPP legislation, the inconsistent legal system, incomplete legislative system, and other issues that make the issue of rent-seeking of power frequently occur.

First, the PPP model lacks legislation at the national level, and it is difficult for PPP pension programs to have laws to follow. At present, most of the laws and regulations related to PPP projects in China are regulatory documents such as local governments and the State Council, and the implementation efficiency and the level of legislation are not high. Second, the laws of China's PPP pension programs lack specificity and pertinence. The procedures of the PPP pension program are complex and changeable, and loopholes in the law have given the government more options to make the rent-seeking phenomenon of power more and more common.

\section{B. The profitability of the private sector}

As a quasi-public product, the pension institution itself has a high risk and a slow return, which makes ordinary private enterprises worry about and hinder the entry into the field of endowment insurance. Although the introduction of the PPP model can reduce investment risks, the private sector pursues profitability. This contradictory nature with the public interest determines that any industry that may suffer losses will affect its entry. 


\section{The elderly have limited income and insufficient ability to pay}

The current purchasing power parity pension model focuses on user fees, and limited sources of income for the elderly limit the ability to pay for pension services.

There are three main sources of income for the elderly: family members' support, labor income, and retirement benefits. According to the 2010 census data, urban seniors mainly derive their income from pensions and pensions, which is $66.3 \%$. The source of income for the rural elderly is mainly from other family members, accounting for $47.74 \%$ of the rural elderly. The labor income ratio is $41.18 \%$. For the urban elderly, although the urban elderly pension ratio is relatively high, pension income still cannot make up for the living standards of the elderly. For the rural elderly, as the process of urbanization accelerates, young and middle-aged people generally go out to work and the number of empty-nest families continues to increase. The function of the elderly relying on their children's pension will inevitably weaken.

In general, the expenditures of elderly people in urban and rural areas on pension services are generally low, which is in stark contrast to the principle that paying users as the main payment mechanism for endowment PPP projects.

\section{COUNTERMEASURES AND SUGGESTIONS FOR IMPROVING THE PPP MODE OF COMMUNITY ENDOWMENT IN CHINESE COMMUNITY}

The PPP model of community-based home-based care is targeted at the aged population. Therefore, the quality of service is the key to the success of a project. This is also a difference from general commercial projects. To this end, we should start with the following aspects.

\section{A. Formulate and improve corresponding laws and regulations}

From the perspective of the overall PPP project, it is necessary to establish and improve the legislation at the national level and formulate detailed PPP operation guidelines and standards so that the PPP pension model can be implemented in accordance with regulations and standards can be better achieved.

In order to smoothly promote the PPP pension model, it is necessary to formulate and improve corresponding policies and regulations. The first is to formulate detailed and specific policies related to the PPP pension model and make clear instructions on all aspects involved in the PPP pension model. This will enable some form of assessment to play a real role and reduce the possibility of rent-seeking power. The second is to strengthen the PPP performance evaluation system, establish a pre-and post-event, post-event performance evaluation management mechanism, establish various specialization teams to supervise all aspects of the project process, and make the operation of pension institutions more standardized and professional [7].

\section{B. Increase policy support for private enterprises}

Due to the large investment in the early stage of the pension service industry, the slow returns and high risks, the private enterprises are deterred. Therefore, the government needs policy support to incite private capital into the field of pension services.

The first is to create a good institutional environment and mobilize the enthusiasm of private capital. Through the introduction of private capital to enter and withdraw from the pension service sector mechanism, ensure that private capital and public institutions are relatively equal in legal status, and create a fair and orderly operating environment for private enterprises. Second, the state should clarify the specific support policies that encourage private capital to enter the pension industry, such as the provision of specific subsidy standards, and vigorously support private enterprises in their involvement in the pension industry.

\section{Improve the Social Security System}

With the acceleration of urbanization and industrialization in our country, the traditional bond for the elderly to obtain economic security from their children is increasingly fragile, and the private transferable income of the elderly within the family is increasingly less rigid [8]. Moreover, with the growth of age, the physical condition of the elderly does not allow heavy labor, so a sound social security system is imminent.

First of all, the government must increase the financial transfer payment, ease the imbalance between pension supply and demand, and meet the retirement security of low-income seniors who have already retired [8]. Secondly, we must improve the corresponding laws and regulations, improve the rural social endowment insurance system legislation, narrow the welfare gap between the urban elderly population and rural elderly population, and ensure social equity. Thirdly, the dual pension system will be abolished, and the pension gaps for retired employees in enterprises and institutions and institutions will be reduced to gradually realize social equity. Finally, it is possible to gradually extend the retirement age in different industries and not engage in "one size fits all".

\section{SUMMARY}

Under the PPP model, the government and the private sector fully integrated the beneficial resources of both parties to carry out the construction of endowment projects. This not only achieved a win-win situation for all participating units and individuals of the PPP pension program, but also benefited all users of pension projects [9]. In China, due to the short period of application of the PPP model and the lack of practical experience, the PPP model of community endowment insurance needs further research and analysis. Gradually improve the government's ability to perform duties in the practice, and promote the PPP model of the community home-based endowment to develop in the direction of normalization. 


\section{REFERENCES}

[1] Wang Wei. The application of PPP model in community home-based care for the elderly: Taking Shanghai as an example [J]. Reform and Opening, 2016(01): 85-86. (In Chinese)

[2] Xu Mengwei. Research on the basic mode and countermeasures of PPP mode linking community home care service [J].Labor Security World, 2017(33):13-14. (In Chinese)

[3] Cao Lei. Research on risk of PPP project in pension service industry [J]. Journal of Chongqing University of Science and Technology (Social Sciences Edition), 2017(06):52-54+57. (In Chinese)

[4] Gao Kaiying. PPP model applied to the study of home-based care in Chinese communities [J]. Modern Management Science, 2015(09):82-84 (In Chinese)
[5] Yang Hairong, Ding Fuxing. Problems and Countermeasures of Longterm Nursing Service PPP Supply Mode in Suzhou City [J]. Labor Security World, 2017(24):27-28. (In Chinese)

[6] Li Wenqin, Shi Yuanru, Li Ling. PPP project risk in pension institutions [J]. China Finance, 2017(08):58-59. (In Chinese)

[7] Yu Meihui. Study on the Pefection of PPP Mode in the Development of China's Pension Industry [D]. Qingdao University, 2017. (In Chinese)

[8] Jiang Xiangqun, Wei Meng. China's current state of social pension insurance development status and problems and policy analysis [J]. Northwest population, 2015, 36 (02): 77-81 +86. (In Chinese)

[9] Li Jing, Li Yutong, Jia Shuailing, Chen Xu. Study on the risk dissolution of endowment insurance in PPP mode [J]. Modern Business, 2017(30):188-189. (In Chinese) 